\title{
CAREER CHOICES OF PHD GRADUATES IN THE SOCIAL SCIENCES AND HUMANITIES
}

\begin{abstract}
How successful are PhD graduates in the Social Sciences and Humanities when stepping out beyond the academic setting, or else entering professional circles within the academic structures, namely research and lecturing positions? The aim of this article is to present partial results of a qualitative research undertaken in Slovakia as a part of the international POCARIM project, mapping career paths of PhD graduates in Social Sciences and Humanities. This article discusses various aspects shaping career paths of such graduates. The empirical sampling provides facts for our reflection regarding qualified researchers and their experience. Each respondent has his/her own life story and the analysis is accompanied with some of the actual examples. It shows how the decisionmaking process can develop and what directions a career path can take. Based on narrative accounts, basic factors affecting a postdoctoral course of life were identified and analised from three basic points of view, namely: gender, economic and individual.
\end{abstract}

Key words: career, PhD, Social Sciences and Humanities, graduate

\section{INTRODUCTION}

The current situation in higher education is marked by economic restraints concerning investment in all fields of scientific training, both on the national and European level. The public pressure regarding overall expenditure cuts in science has led to serious questioning of the role of investment in the Social Sciences and Humanities (SSH). "In some countries the expenditure in the SSH field has faced disproportionate cuts reflecting a belief that these disciplines are less important to economical growth and productivity, and

${ }^{1}$ PhD; Univerzita Mateja Bela, Banská Bystrica; dagmara.majerova@umb.sk. 
as such they should receive a lower level of public subsidy." Along with the continuous restraint on investment there comes a need of "an evidencebased justification for continued or potentially more focused investment". The POCARIM project, therefore, was developed to respond to this challenge, its aim being to map the career paths of doctoral graduates in SSH in 13 partnership countries. In the broad sense, the study aspires to capture the diversity of professional career paths, employment trends and the impact of SSH doctoral graduates in Europe. The aim is to comprehend the patterns of employment trends and job searches of $\mathrm{PhD}$ graduates in $\mathrm{SSH} .{ }^{2}$

The research of the POCARIM project is focused on several areas. Our quantitative research provided us with data on the career paths of young scientists who graduated with a PhD degree between 2000 and 2012. A total of 130 questionnaires were collected from an online survey. The basic questions that were asked aimed at finding out how the career path of a respondent had developed. Subsequently, there were 25 individual meetings each with a different PhD graduate. The method of a semi-structured interview was employed and many details related to their professional life were added to the questionnaire data. The focus was on the account of their career paths, the ways of benefitting from mobility opportunities during their studies and their ensuing professional position in the academic environment or elsewhere, and what impact their knowledge, research experience and work has had on society. We were interested in the following: the extent of interdisciplinarity and the intersectoral character of their work; what the first steps in their career were; whether postdoctoral students wish to stay in the academic environment or whether their choice is to go into a different sector; and, if so, what their motivation is.

As far as the exploratory sample is concerned, our intention was to ensure variety. Therefore, respondents from various scientific fields, of different ages, and from different parts of Slovakia were addressed. The only criterion was graduation with a PhD in SSH within the years 2000 and 2012. Additionally, we used also secondary data from the Institute of Information and Prognoses of Education providing statistics on the number of doctoral graduates between the years 2003 and 2012.

\footnotetext{
${ }^{2}$ L. Ackers, POCARIM. Mapping the Population, Careers, Mobilities and Impacts of Advanced Research Degree Graduates in the Social Sciences and Humanities. Proposal for FP7-SSH-2011-3 Supporting Action 8.8.3, Career Paths and Patterns of SSH Graduates, Liverpool 2009, pp. 3-4.
} 
This article will reflect upon various aspects affecting the career paths of the PhD graduates following their completed studies when entering the job market. The research shows there are several economic, social and individual factors which play a significant role in the decision-making process regarding their future steps.

Doctoral studies are generally understood as training for a scientific career and whose aim is to carry out research which should demonstrate student's ability to conduct independent scientific work. ${ }^{3}$ From a different point of view, one culturally determined by our social setting, such research studies can be perceived as a kind of "interim period" for young scientists who are at the beginning of their career and have decided to dedicate their life to science. The "interim period" is meant in the sense that, on one hand, the expected outcome of doctoral studies is scientific research contributing to the development of general scientific knowledge, as well as to one's personal knowledge and skills. On the other hand, the position of research student in the academic environment is not clearly defined. Sometimes doctoral students fall within the regulations, terms and guidelines of a university or a scientific institute generally applying to students. In other instances, they are expected to fulfil their duties and act upon their rights as members of a team with an employment contract.

\section{GENDER ASPECTS OF A RESEARCH CAREER}

Based on the statement of the Institute of Information and Prognoses of Education, the number of $\mathrm{PhD}$ graduates in Slovakia is gradually increasing. ${ }^{4}$ During the period 2000-2008, the number of PhD students at Slovak universities grew by $85 \% .^{5}$ Many new fields had qualified to obtain an accreditation in advanced studies of higher education. Moreover, in

${ }^{3}$ Idem, "Moving People and Knowledge: Scientific Mobility in the European Union", International Migration, vol. 43, no. 5 (2005), pp. 99-131.

4 „Ústav informácií a prognóz školstva (2003-2012)”, Štatistická ročenka - vysoké školy, Bratislava 2012, at http://www.uips.sk/prehlady-skol/statisticka-rocenka---vysokeskoly, 13 July 2016.

${ }^{5} \mathrm{~J}$. Helbich et al., Akademická kariéra výskumných a pedagogických pracovníkov na vysokých školách v SR a možnosti jej optimalizácie, Bratislava 2009, http://www.minedu. sk/akademicka-kariera-vyskumnych-a-pedagogickych-pracovnikov-na-vysokych-skolachv-sr-a-moznosti-jej-optimalizacie/, 13 July 2016. 
some particular fields of $\mathrm{SSH}$, there are more women becoming interested in gaining a scientific qualification. The statistics show a narrow majority in the following fields: education, psychology, linguistics, literature, cultural studies, history of art, economics and business studies, mass media and communication studies. ${ }^{6}$ As a consequence of the fact that in these fields there is a higher percentage of women who attained PhD degrees, the interest of women in higher education in SSH has generally increased, as well as their concern to continue in the academic environment after their graduation. In total, the share of women with an academic qualification is $35.3 \%$. However, there is a survey which shows that the share of women is generally increasing among younger scientists, with $42 \%$ of women employed in research and science out of all scientists up to the age of 35 . However, the lower share of women is apparent. ${ }^{7}$

Nevertheless, the Statistical Office of the Slovak Republic did not consider the question whether the young women had had a family with children at the beginning of their career. This fact has a considerable impact on the career choice of a young female scientist. The character of social patterns of women represents a significant aspect influencing their behaviour. Deciding between a career and the family results in a conflict of roles as it involves the issue of a woman's identity. In contrast, there are women who do not experience such conflict as the career is their clear priority. ${ }^{8}$ However, we did not encounter such a case in our investigation. Every interviewed woman had certainly considered the conditions required for having a family while deliberating her career path. Some women choose the academic path after their graduation as they believe that they can start a family and care for children along with their research studies and work on their dissertation. This seems to raise their opportunities in finding a post as if being a subject with a higher probability of a perspective maternity leave. Many women start their doctoral studies with a genuine zeal for science. Therefore, they postpone the steps towards starting a family. Later, those women who have not already started their family

6 „Ústav informácií . . .", op. cit.

${ }^{7}$ Výsledky mimoriadneho štatistického zistovania o kariére držitel'ov doktorátov v SR (CDH 2006), Štatistický úrad SR, 2008, http://portal.statistics.sk/files/Sekcie/sek_500/ Veda-a-technika/publ/Publikacia_CDH2006.pdf, 21 January 2016.

${ }^{8}$ W. Patton, M. McMahon, Career Development and Systems Theory. Connecting Theory and Practice (2nd ed.), Rotterdam 2006. 
before completion of their doctoral studies usually have difficulties finding employment, facing various disadvantages due to their age and gender. Generally, the position of women and post-doctoral researchers is uncertain. The age of beginning their career corresponds with the age of starting a family, ${ }^{9}$ and the employer considers this fact when deciding on a type of an employment contract for a new young scientist. Principally, at Slovak universities and research institutes, the length of the first employment contract for a young researcher is usually offered for one year. After this period, the researcher has to enter a competition for the same position again. A new contract is considered and if renewed, it is usually again for a year, sometimes for three. The third renewal of the contract may be for five years. Based on the respondents' answers, currently, this is the longest possible contract. Nowadays, only fixed-term contracts are being offered at our universities. This leads young female scientists into being under time pressure when trying to harmonise the starting of a family and their career. At the present time, a young scientist who wishes to work in the academic environment has to consider her or his priorities carefully and use the time provided for building their career in a consistent manner. If a woman wants to start a family, she should do that immediately after signing a contract. However, there is a possibility that during her maternity leave the contract will be terminated and she will be replaced, or her position will not be opened again.

I have a fixed-term contract and that is the worst possible option. It might not be renewed. Unsurprisingly, the fact that I am a woman of certain age who might want to start a family will be considered, and this can be a reason for not getting a new contract. (Female, 33, Research Assistant - University Lecturer)

The answer to the question whether the respondent is postponing starting her family is as follows:

Yes, exactly. My contract was renewed three times and next year I have to enter the competition again. My colleague did, and her contract was renewed for three years, then she needed to become pregnant as soon as possible to stay on maternity leave for a year and then to come back quickly, there would

${ }^{9}$ L. Husu, Sexism, Support and Survival in Academia. Academic Women and Hidden Discrimination in Finland (1st ed.), Helsinki 2001. 
be still a place for her. This is how female researchers have to plan their life they would have at least a small chance to come back. That is exactly the situation at our institute. During the last two years there were 6 or 7 women who went on maternity leave. And soon there will be another boom, because we are compelled to. I have some colleagues at the same age. I'm 33 and I think that I would like to have a family already, but I have to wait for the renewal of my contract. (Female, 33, Research Assistant - University Lecturer)

In the public sector the state doesn't regulate that the duration of a contract should not be counted during maternity [leave] and it should be intermitted. And that's wrong. If a young female scientist wants to go on a maternity leave, her contract can be terminated during maternity leave. If I imagine that with contracts in education, you get them for a year or two, I think, the maximum is three years. You can get one for five years after having renewed a contract three times. The reality is such that a young female researcher gets usually only one or two years. Take that the young women are approximately 25 when they start their doctoral studies, they finish them at 29 and then they get a contract for a year or two. What about the children? There's no logic and it concerns men as well. So paternity leave is not an option. This is one of the reasons why I was taking into account rather the Slovak Academy of Sciences or other Slovak institutes, because it's an important motive for me. (Female, 30, Research Assistant at the Slovak Academy of Sciences)

This respondent's main decision-making criterion about her career was the potential of having a family in the near future. The next statement shows a negative attitude towards an applicant who was pregnant during the selection process in an employment competition. She should have been offered a part-time contract as an internal member of a university institute. However, the board decided to offer her only an agreement contract despite the fact that the researcher was able to harmonise her work with her family life. In an agreement contract, the employer is not obliged to provide various benefits as in an employment contract. The respondent decided to accept this offer, because she wanted to stay in contact with the academic environment and the research team despite the fact that her remuneration and social benefits resulting for the agreement contract were not adequate for her as a university lecturer.

I would like to stay at the university up to a point. But now my situation is actually insoluble. When I said to our head that I am pregnant, it was absolutely out of the question and he refused to talk about it any further. The women, who work there, they were fine, they could imagine that it would be possible. 
I will deliver the baby in summer which means I could give lectures before that and afterwards as well, but the professor did not agree. He simply closed the issue and there was no space for discussion, simply I am pregnant and there's no need for other questions. Still he wants me to cover some subjects, because one of us has left. This means I will be lecturing even more, but only as an external, not internal employee. (Female, 30, Consultant, International Company)

On the other hand, female researchers are well aware of the advantages present at universities. Generally, the working hours are not strictly fixed and controlled and the researcher, who is a mother, can use her time for work and family more flexibly. However, this condition has also another aspect as, in fulfilling the traditional role, a woman is expected to take care of the household and management of the whole family. Therefore, female researchers cannot work in linear manner (uninterrupted research activity), these women work more in cyclical manner (with breaks for childcare and household chores) and this prevents them from absolute and continual concentration on work and thus from progress on the career ladder. ${ }^{10}$

So, my personal observation is that for women who have children it is an advantage to work at university. I do not think that they are more burdened then women in other professions, not at all. And you can see that easily. There is more space for time management and even to create required time break even in the normal working hours. So I believe it is also about personal responsibility as it can easily fall into deterioration when personal issues start to prevail over the working time or vice versa the working issues in free personal time. So the risk is in neglecting the time management with a benevolent approach. (Female, 31, Research Assistant - University Lecturer)

Now, if I was to make a decision whether to come back to business or to academic environment, I would rather choose the academic one, because with a child it is an ideal place for combining everything together. But on the other hand, I do not want to go back to the fundamental research which I was doing. I shall see where my steps will lead to. Maybe, at the end, I will go back to that, because when working in business, I used to sit there until 7 p.m., and that is not possible with a child, I can't imagine that. (Female, 30, on maternity leave)

${ }^{10} \mathrm{H}$. Havelková, "Některé teoretické a praktické aspekty problematiky žen ve vědě", Gender, rovné přiležitosti, výzkum, 4 (2001), pp. 36-42, http://www.cec-wys.org/kontext/ff83091c/08_mladi_alice.pdf, 22 February 2016. 


\section{THE ECONOMIC ASPECTS OF A RESEARCH CAREER}

According to research conducted by Tampoe ${ }^{11}$, the motivation among educated people is projected into more than one area. The first position is taken by a need for personal development, followed by autonomy in working tasks, a sense of success and satisfaction with one's work, recognition by the employing organisation, as well as remuneration. The position of salary is influenced by a number of factors. However, it remains a specific work motive. ${ }^{12}$ The financial reward is an instrumental tool for providing the one's basic needs and securities and may be perceived also as one of the means of achieving a certain social status. ${ }^{13}$

The statistics for the year 2008 prepared by the Statistical Office show that $61 \%$ of qualified researchers work in a field relevant to their expertise, while the majority of doctoral students plan to pursue an academic career building on their present research activities. ${ }^{14}$ In spite of this, the choice of employment presents a very complex problem. The economic aspect, in the sense of salary and benefits, has a significant role. However, in the academic environment the financial remuneration is not very motivating, as evident in a survey from the Statistical Office of the Slovak Republic. The highest dissatisfaction was expressed by PhD-qualified researchers over their position in the pay structure and the benefits resulting from this professional classification as set by the government. ${ }^{15}$ In fact, the base of their salary is lower than the average wage in Slovakia, while net pay is even lower than a scholarship for doctoral students. Many doctoral graduates revise their choices about future work in research. If a young scientist has not established himself at an academic institute or has been not working on one of the larger international projects, his or her perspectives are virtually

${ }^{11}$ M. Tampoe, "Motivating knowledge workers - the challenge for the 1990s", Long Range Planning, no. 26(3) (1993), p. 49-55.

${ }^{12}$ G. Kravčáková, J. Lukáčová, T. Búgelová, Práca a kariéra vysokoškolského učitela, Košice 2011, http://www.upjs.sk/public/media/5596/Praca-a-kariera-vysokoskolskehoucitela.pdf, 12 February 2015.

${ }^{13} \mathrm{~J}$. Lukáčová, Miera pracovnej spokojnosti doktorandov, in: T. Búgelová, G. Kravčáková (eds.), Hodnota duševnej práce pre organizáciu a spoločnost'. Zborník vedeckých prác z výskumného grantu VEGA č.1/0865/08. Determinanty, kritériá a hodnotenie duševnej práce, Košice 2010, pp. 277-288.

${ }^{14} \mathrm{~J}$. Helbich et al., Akademická . .., op. cit.

${ }^{15}$ Ibid. 
very narrow. In the academic environment, the opening of positions is rare and there is an increase of the phenomenon of holding an insecure position (postdoc). ${ }^{16}$ Even if there is a postdoc position opened, they usually fulfil the function of "cheap labour" at universities. ${ }^{17}$ After graduation, only a small number of PhD graduates continue with their work in the academic environment. There is no transparent system of publishing job postings, the selection criteria are not defined clearly and appropriately and there is favouritism being employed to a great extent. These practices are not very motivating. Therefore, young scientists rather decide on a different career path which often does not correspond with their achieved qualification.

There is a gender aspect present again in the decision-making process regarding employment positions. Here, the gender stereotype viewing the importance of man's role as the provider of the family is involved. ${ }^{18}$ Specifically, it is an economic role. Therefore, men also face a difficult choice whether to stay in science, thereby bringing down the living standard of their family, or to abandon their original desire to work in academic research. They are often forced to reach out for alternative solutions of their employment and turn to private economic sector where they can find more possibilities for career advancement and, thus, financial reward as well. Some of them try to follow "the golden mean" choosing positions where they can partially utilise their knowledge and experience acquired during their doctoral studies.

... well, it was a tough period of my life. It wasn't easy to make it in archaeology even with a PhD, especially, when one has to consider also others not just himself. During my doctoral studies, I started my family and this changed my attitude to life. I couldn't work for a pittance anymore, which we used to get for our research. One does not take into account the type of work any longer and takes what comes even it is far away from one's expertise. My priority was to stay in my field at least to some extent. I have dedicated a great part of my life to that and there is quite a bit of hard work behind it. Still, I had great difficulties to find a job. In the time after my graduation, I was entering

${ }^{16} \mathrm{~A}$. Červínková, "Věk, gender a věda: problematická situace mladých vědců a vědkyn̆", Kontext: časopis pro gender a vědu, 1 (2003), at http://www.cec-wys.org/kontext/ff83091c/08_mladi_alice.pdf, 20 July 2016.

${ }^{17}$ Ibid.

18 "Rodové stereotypy", Glosár rodovej terminológie. Aspekt, 2006, at http://glosar. aspekt.sk/default.aspx?smi=1\&ami=1\&vid=119, 20 July 2016. 
competitions even outside my field and I was reconciled with the fact that I won't work in archaeology anymore. And then, there came an offer from the Monuments Board of the Slovak Republic [The Slovak National Heritage Board] and that was the chance. I could stay in my field and at the same time to bring some change and contribute to the better standard of the archaeological ambit. (Male, 32, an employee of the Monuments Board)

Those qualified PhD researchers who stayed in the academic field often emphasise an excessive workload which has an impact on the quality of their work and remains without adequate financial reward. The nature of their responsibilities is often not delineated by their working place. Thus, they take their work home and their personal and professional life blend into each other. There are many workplaces where the working time is not strictly set at 8 working hours at the prescribed workplace. However, this can result in such situation that researchers work on their projects or undertake the administrative tasks in their personal time.

On one hand, we are not bound by strict working hours and on the other, one has to take the work home. The preparation of the lectures is done at the dining table, and then, when finalizing the projects, sleepless nights come and one has to be with it in his personal time. On the other hand, I can pick up my daughter from the nursery at the time I need to or take her to the doctor. There is no control over that whether I'm physically present at work, except the lectures and consultation hours, of course. The physical presence isn't required, but it doesn't mean that I don't have to present the results of my work, because I was with my daughter. When she goes to sleep, I sit in front of my computer until late at night. And I keep thinking for myself what the sense of this toil for the pittance is. (Female, 31, Research Assistant - University Lecturer)

At some university institutes, it is not an issue to have another parttime job or an agreement contract elsewhere. Nonetheless, the responsibilities of research assistants are so time-demanding that it is practically impossible to dedicate some time to other employment activities.

I would like to have another job where I could relate my work to practical applications. The responsible ones at the institute say, it's o.k., but you can do that during your vacation. Why work during my vacation instead of relaxing, no way. If I had in my contract the space for that, I would like to work as a counselling psychologist or at least to practise psychological diagnostics. . . . We are so overloaded here. I would simply have to put away some of that to manage 
two jobs. A university lecturer could go into practice but the lecturing would have to be part-time and it doesn't make sense to stay in such position. It's the money that give us bread. So it's not easily done. To cut down such a small wage by changing your contract to a part-time one is an unrealistic nonsense. (Female, 45, Research Assistant - University Lecturer)

In cases where graduates focused on different field outside academia, they claim that their PhD qualification is an ineffective encumbrance or without any relevance and value. Some of the respondents have encountered negative response from a potential employer. They were considered to be overeducated or ineffectual in practical areas, because their experience was oriented towards science which, in many cases, does not have any relevance to practical issues and reality. Some of them have encountered rejection because their education was higher than the education of their prospective manager. This can be a problem for companies and especially for particular managers as it brings down their business reputation.

Exactly, my PhD qualification was an obstacle in different sectors than the academic one. It was shown to be a handicap for employers. Usually, I had higher qualification and they thought they would not be able to offer an adequate salary. Well, in the different environment they believe it's too academic and they didn't know how to utilize my education. The position I work at now doesn't require PhD qualification. (Female, 31, Project Manager in the Public Sector)

I don't regret the decision to gain a PhD qualification. However, when I was teaching at the secondary school, the PhD was absolutely ineffective. It wasn't applicable, neither from the economic perspective nor from the professional one. It was even counter-productive in relationships with my colleagues who were thinking that my doctoral studies were about my self-importance. (Female, 35, Research Assistant - University Lecturer)

Another answer to the question about the effect of a PhD qualification in the selection process for their present job is as follows:

... there was no outcome at all. They were not interested in the level of qualification. There are even many people only with a college certificate. And they are in senior positions. (Female, 28, Accountant, International Company)

I was told right at the beginning that my CV was filed as the last one. My colleagues expressed many times, while I was working there, that it was 
absolutely discouraging for them, my profile, that I was never doing anything normal, being too clever, coming here and for sure I will want to pursue a career at a flying speed, because I have PhD. (Female, 30, maternity leave)

The desire for a career growth is, for many PhD-qualified specialists, a reason for leaving their home town or their current place of living. In the case of a position offered in another region, they are willing to relocate and temporarily, or even permanently, settle in the place of their work. For qualified researchers, the economic motivation for migration is a common phenomenon. When the most educated people leave the less attractive parts of Slovakia in order to find an employment in the parts where suitable jobs are offered, it is possible to speak of a "brain drain". Only two of the interviewed respondents gained a long-term postdoctoral internship abroad. However, many of the respondents did not reject the option of relocating to a foreign country in the future if they were offered a post in their field with adequate remuneration. Thus, they would raise their chances of finding employment later in Slovakia, where experience gained from foreign countries is still highly valued. Nevertheless, this possibility was not acceptable for those who were in a long-term personal partnership or married. The fact of having a family or a partner has an impact on the decision-making process of the PhD-qualified researchers about the employment in a different location. Jacob Mincer ${ }^{19}$ explained this in his study where he related work migration with the family context. The place of employment is influenced by an individual approach towards personal life and family. Mincer based his theory on the fact that spouses or partners make the decision whether to relocate together and the family interests are placed prior to personal success. If the relocation should cause greater loss for one partner, it is not pursued..$^{20}$ One can find evidence of this in the following statement of a respondent who had to make decision where to do her doctoral studies and then again whether to stay in her current location after her graduation.

${ }^{19}$ J. Mincer, "Family Migration Decisions", Journal of Political Economy, vol. 86, no. 5 (1978), p. 749-473.

${ }^{20}$ A. Červínková, "Postdokovat po světě: genderové politiky akademické mobility", Gender, rovné príležitosti, výzkum, 11, no. 1 (2010), pp. 49-59, at http://www.genderonline.cz/uploads/0874692f4c84cc0408d86164faaf073f38937b6b_postdokovat-po-svete. pdf, 20 July 2016. 
And I have a partner here, my husband, that was the reason why I decided to study at the Slovak Academy of Sciences and not abroad. It would be nice to go abroad for a postdoc internship, but my husband is employed at the moment, he finished his studies and got an academic post, he is at the university. First, we travelled because of me [six-month international internship for doctoral students], so now we stay home because of my husband and I suppose that after my maternity leave we will go to something like a Fullbright, or so. It's possible to go there with the family and you get higher pay. (Female, 30, Research Assistant, Slovak Academy of Sciences)

\section{INDIVIDUAL ASPECTS OF A RESEARCH CAREER}

According to the PhD graduates in SSH, the academic setting is often not sufficiently interrelated with the current reality - on the one hand, the problems are seen from an academic distance and, on the other, the application of research is not being carried out. For professional establishment in the university environment, young scientists need to obtain work experience outside the academic setting. They believe that they can also apply their knowledge and skills acquired during their doctoral studies in other sectors and, at the same time, increase their chances on the job market. This argument was asserted not only by the qualified researchers who are employed in a different sector, but also by academic staff.

I even got a lecturing offer in economics from the Technical University in Košice. Yet, I said to myself, not university now, but practical life. (Female, 28, Accountant, International Company)

And I was not planning to stay at that place after my graduation when I was starting my doctoral studies. I really wanted to get some professional experience from the practical field and then maybe to come back. That would suit me. But not to stay at the institute without real life experience. What would I present to the students? Just empty definitions? (Female, 29, Project Manager, Public Sector)

I wanted to go back to the profession on practical grounds, at least on parttime basis and I believe it is a great mistake that university lecturers don't have opportunities for that; to practise their knowledge. That's what should be every lecturer inspired by or it should keep him to the ground as well. Put simply, then at the lectures they wouldn't present such rubbish which is far away from the reality. (Female, 45, Research Assistant - University Lecturer) 
Červínková (2003) using the term "insecure position", described the postdoctoral students in situations of such positions, even during their studies. Academic institutes sometimes promise a contract before graduation, and when completed the promise is not fulfilled. There are more factors entering the scene which influence the decision whether to accept the graduate or not, especially the financial factor that means an insufficient budget, or the social factor which involves personal relationships with the graduate student at the institute.

I was very keen in staying at the institute as a researcher. Everything was indicating that I would because there was a new director, so I hoped that she would retain me. It was my big dream to work in science. And also, considering that I was the first and one of two doctoral students of a professor who was at his retirement age. ... The seniors were leaving, I was meeting the required conditions, I gave birth to children and finished my doctoral studies. So I was hoping for that. Still, the director said, I should forget about it. So they do not have any specialist in my field at the institute and it is slowly dying out. (Female, 42, General Director, Cultural Institute)

Moreover, the structural conditions of our society significantly influence the strategies of our decision-making process about one's future career path. Several respondents stated that they were very fortunate as, at the time of their graduation, nearly every university was undergoing personnel restructuring. In the year 2009, there was a general reaccreditation at Slovak universities with a requirement to adjust the number of employees to the number of students. As many academic institutes did not meet this requirement, they were obliged to recruit more employees than previously. In this manner, there were some positions opened for several young scientists who had just graduated at that time.

It was chaotic, because at the end of the summer there were echoes that no positions would be opened, as there are too many people employed at our university, but gradually, after two months the situation radically changed and I can say that all the doctoral students found a job at our institutes, except one. Most of us who graduated that year were employed and stayed. Still, I do not know whether they are there until now, but at that time they were. (Female, 31, Research Assistant - University Lecturer) 


\section{CONCLUSION}

This study has pointed out several aspects involved in the decision-making process of qualified researchers in SSH regarding their life paths, particularly their careers. This article considers various life situations of young scientists being tossed into insecure positions after graduation and trying to find employment. The European Union is engaged in improving the situation and increasing motivation to foster interrelations and cooperation among the member countries by various steps and arrangements. Progressively, the European Research Areas (ERA) and the European Higher Education Area (EHEA) are being created. One of the main tools is a well-developed system of mobilities, internships and grants, which should provide young researchers with opportunities for professional growth and, at the same time, take care of their motivation to return to their home country, where they would be able to utilise their experience and knowledge. The European Commission asserts its endeavour to interrelate scientific research and societal challenges. However, as many doctoral graduates have stated in their interviews, there is still a great problem to interrelate scientific research with the economic sector within the job market.

\section{BIBLIOGRAPHY}

Ackers L., POCARIM. Mapping the Population, Careers, Mobilities and Impacts of Advanced Research Degree Graduates in the Social Sciences and Humanities. Proposal for FP7SSH-2011-3 Supporting Action 8.8.3., Career Paths and Patterns of SSH Graduates, Liverpool 2009.

Ackers L., "Moving People and Knowledge: Scientific Mobility in the European Union", International Migration, vol. 43, no. 5 (2010), pp. 99-131.

Červínková A., "Věk, gender a věda: problematická situace mladých vědců a vědkyň", Kontext: časopis pro gender a vědu, 1 (2003), at http://www.cec-wys.org/kontext/ff83091c/08_ mladi_alice.pdf, 20 July 2016.

Červínková A., "Za 2 roky doktorát, za 3 dítě, stáž v USA: vědecká dráha v kontextu biografického plánování", Kontext: časopis pro gender a vědu, 2004, at http://www.cec-wys.org/ kontext/399fd221/kapitola_2.pdf, 3 November 2015.

Červínková A., "Postdokovat po světě: genderové politiky akademické mobility", Gender, rovné príležitosti, výzkum, 11, no. 1 (2010), pp. 49-59, at http://www.genderonline.cz/ uploads/0874692f4c84cc0408d86164faaf073f38937b6b_postdokovat-po-svete.pdf, 20 July 2016.

Havelková H., "Některé teoretické a praktické aspekty problematiky žen ve vědě", Gender, rovné príležitosti, výzkum, 4 (2001), pp. 36-42, at http://www.cec-wys.org/kontext/ ff83091c/08_mladi_alice.pdf, 22 February 2016. 
Helbich J. et al., Akademická kariéra výskumných a pedagogických pracovníkov na vysokých školách v SR a možnosti jej optimalizácie, Bratislava 2009, http://www.minedu.sk/akademicka-kariera-vyskumnych-a-pedagogickych-pracovnikov-na-vysokych-skolach-v-sr-amoznosti-jej-optimalizacie/, 13 July 2016.

Husu L., Sexism, Support an Survival in Academia. Academic Women and Hidden Discrimination in Finland (1st ed.), Helsinki 2001.

Illnerová H., Slovo na úvod, in: A. Kostlán (ed.), Práce z dějin vědy, svazek 3. Semináře výzkumného centra prodějiny vědy z let 2000-2001, Praha 2002, pp. 14-18.

Kravčáková G., Lukáčová J., Búgelová T., Práca a kariéra vysokoškolského učitel'a, Košice 2011, http://www.upjs.sk/public/media/5596/Praca-a-kariera-vysokoskolskeho-ucitela.pdf, 12 February 2015.

Lukáčová J., Miera pracovnej spokojnosti doktorandov, in: Búgelová T., Kravčáková G. (eds.), Hodnota duševnej práce pre organizáciu a spoločnost'. Zborník vedeckých prác z výskumného grantu VEGA č.1/0865/08. Determinanty, kritériá a hodnotenie duševnej práce, Košice 2010, pp. 277-288.

Patton W., McMahon M., Career Development and Systems Theory. Connecting Theory and Practice (2nd ed.), Rotterdam 2006.

"Rodové stereotypy", Glosár rodovej terminológie. Aspekt, 2006, at http://glosar.aspekt.sk/default.aspx?smi=1\&ami=1\&vid=119, 20 July 2016.

"Ústav informácií a prognóz školstva (2003-2012)", Štatistická ročenka - vysoké školy, Bratislava 2012, at http://www.uips.sk/prehlady-skol/statisticka-rocenka---vysoke-skoly, 13 July 2016.

Výsledky mimoriadneho štatistického zist'ovania o kariére držitel'ov doktorátov v SR (CDH 2006), Štatistický úrad SR, 2008, http://portal.statistics.sk/files/Sekcie/sek_500/Veda-atechnika/publ/Publikacia_CDH2006.pdf, 21 January 2016. 